\title{
Ei pimeän tunnustelua
}

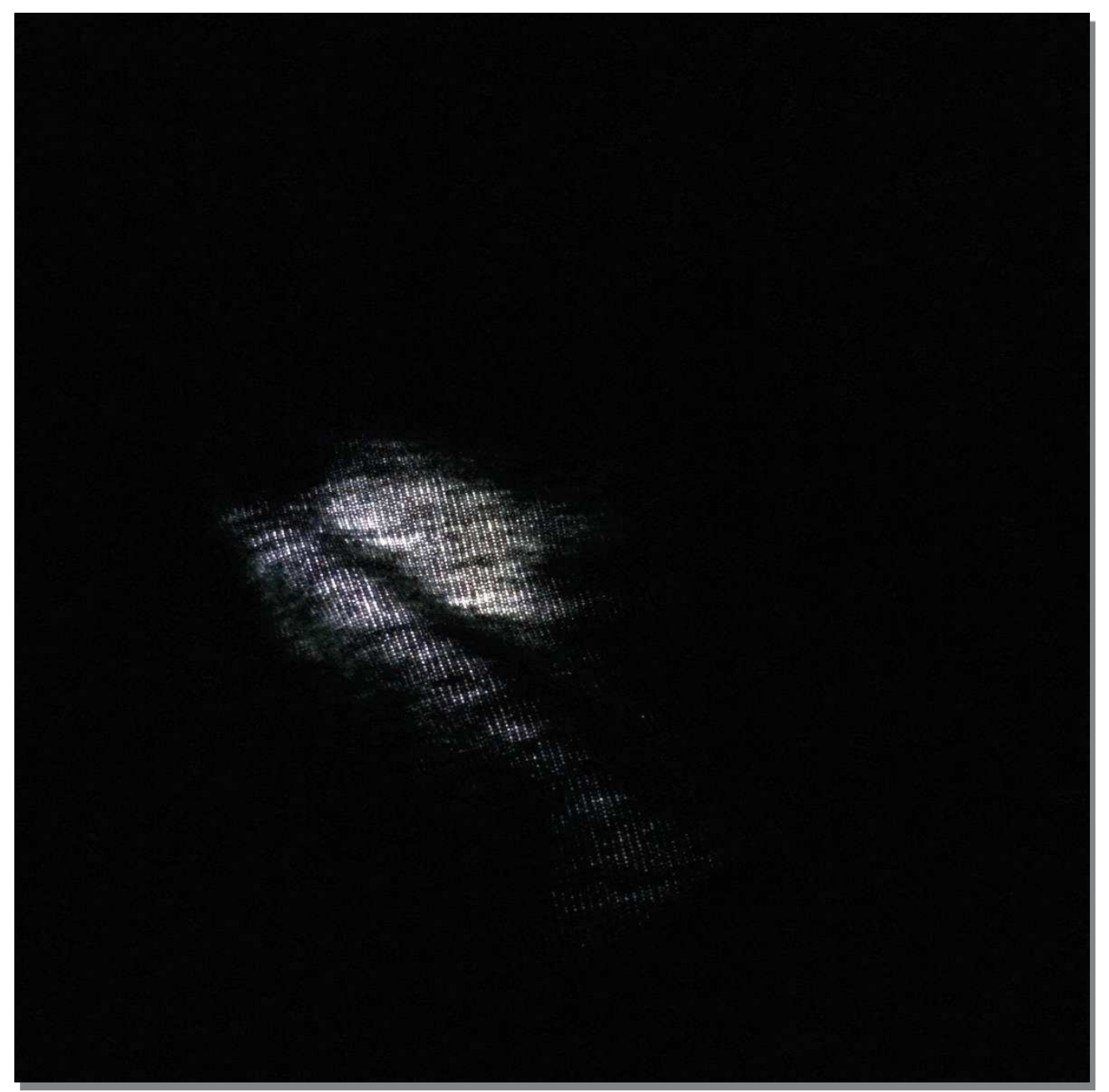

I who can see have my own depth also, being backed up by this same visible which I see and which, I know very well, closes in behind me. The thickness of the body, far from rivaling that of the world, is on the contrary the sole means I have to go unto the heart of the things, by making myself a world and by making them flesh (Merleau-Ponty 1968, 135).

Lying on my back on the fallen trunk and looking at the night sky. I see reddish light covering that sky, and I know through my experience that behind that red curtain, there is a starry sky, and I find myself dreaming about it. There is a disappointment of darkness which seemed to appear as a lightless. I drown between, into intermediate space, not knowing am I in the darkness or in the 
lightless. If the visible exists only with the seer, and the seer with the visible (Hotanen 2008, 85), then the reddish sky opens for my vision in my vision, and through my thoughts and speech I make that visible for me, in my body. I keep dreaming of the starry sky, which stays invisible. There I am, trapped, with the mist of a vision. I cannot see the sky nor darkness, I see reddish colour and lightless, or I sense them. The seeing and sensing are in the same world, now occupied into dark forest, in my embodied being, lying on the fallen trunk, dreaming.

$$
\text { steps }
$$

sounds

$$
\text { flashlights }
$$

I cannot transform myself to be the flashlight of a camera that grabs visions around or a moss I hear steps. I am moving without going and doing. I feel at once I am moving about myself and fully in myself as myself and mine not-self are as much being with a tree as the tree is being with me. I change my position without any particular meaning, just to avoid a discomfort of the rough surface of the trunk.

forest... in the city

darkness ... matter?

Is darkness touchable? Can I take it to my arms and give a hug for it. Can I put it to the glass bowl and watch it through the microscope? And on the whole, do I even need to do so? Can I let it be? Darkness... dark... with little or no light... Darkness lives in light; it lives in stories and narratives... It lives in us. It lively lives in the invisible meanings of the visible. This invisible is not separated from visible; rather it can be reached as the invisible of the visible.

Whatever I imagine or I think of ... I can't avoid to be affected ... as Brian Massumi writes: 
When you affect something, you are at the same time opening yourself up to being affected in turn, and in slightly different way than you might have been the moment before. You have made a transition, however slight. You have stepped over the threshold (Zournazi 2002, 212).

I keep moving without really doing anything or going anywhere and still each single, slight or big movement in the body is a transition, is the step over the threshold. Because, just from the point my body is situated in, I can see the sky, the red curtain (that sees me from everywhere). Every single change in my posture changes the whole forest for me. And through these slight steps and moments, opens a protean world, where is no beginnings and endings, where a form "lives and breathes in the moving flow of its creation [...], a flow experienced as an ongoing present, an unbroken now [...] that is, an ongoing flow of movement from an ever-changing kinetic world of possibilities" (SheetsJohnstone 1999, p. 485). Massumi writes with Mary Zournazi: “[...] affect is thinking, bodily - consciously but vaguely, in the sense that is not yet thought. It is movement of thought or a thinking movement" (Zournazi 2002, 217). I am in the world of possibilities...

\section{References}

Hotanen, Juho. 2008. Lihan laskos: Merleau-Pontyn luonnos uudesta ontologiasta. Helsinki: Tutkijaliitto, Episteme-sarja.

Merleau-Ponty, Maurice. 1968. The Visible and the Invisible: Followed by working notes, edited by Claude Lefort. Translated by Alphonso Lingis. Evanston: Northwestern University Press. https://monoskop.org/images/8/80/Merleau Ponty Maurice The Visibl e and the Invisible 1968.pdf

Sheets-Johnstone, Maxine. 1999. The primacy of movement. Amsterdam: John Benjamin Publishing Company.

Zournazi, Mary. 2002. Hope: New Philosophies for Change. Interview: Navigating movements - with Brian Massumi. Annandale: Pluto Press Australia, 210- 243. 